Marquette University

e-Publications@Marquette

Theology Faculty Research and Publications

Theology, Department of

$4-1-2011$

Ethics Brewed in an African Pot

Agbonkhianmeghe E. Orobator

Marquette University, agbonkhianmeghe.orobator@marquette.edu

Published version. Journal of the Society of Christian Ethics, Vol. 31, No. 1 (Spring/Summer 2011):

3-16. Permalink. (C) 2011 Georgetown University Press. Used with permission. 


\title{
Ethics Brewed in an African Pot
}

\author{
Agbonkbianmeghe E. Orobator, Sf
}

DOING ETHICS IN AFRICAN CHRISTIANITY RAISESTHE CHALLENGE OF OVERgeneralization in the midst of diversity and variety. This essay surveys the wide ethical landscape of Africa, explores key ethical issues on the continent within the context of the world church, and proposes priorities for action in view of a global ethical partnership.

Whe following is a true story. I am a Nigerian. Coming to North America fourteen years ago, I was greeted with the following question by an American: "Would you happen to know my friend in Tanzania?"

To get a picture of how daunting this question was, consider: the average travel time from Nigeria to Tanzania by air is almost the same as from New York to Los Angeles! More than two thousand miles of villages, cities, countries, desert, rivers, and tropical forest separate Lagos from Dar es Salaam. Any chance of running into my interlocutor's Tanzanian friend in the densely populated streets of Lagos seemed mathematically quite slim, if not possible except by chance. This simple story makes a point: it evokes stereotypes, generalizations, and images frequently associated with the idea of Africa in the Western imagination. Perhaps not unsurprisingly in the media-conditioned perception of many people in the global north, Africa is a simple reality, albeit a reality riddled with complex and emergent situations of conflict, diseases, and misery.

In light of this simplistic perception of Africa, a preliminary caution seems necessary: I do not speak for Africa. My experience of the continent is limited to about half a dozen countries out of fifty-three, not counting the colorful and oftentimes confusing blend of cultures, peoples, and languages that constitute the reality called Africa. My first advice to anyone trying to understand something of Africa is to rethink whatever he or she has thought about the continent. Africa is not one thing; it is a million things compressed into a vast geopolitical entity. As such, Africa lends itself to a multiplicity of meanings, interpretations, and controversies. This dimension of cultural, political, social, geographical, and religious diversity should inform how we are to understand ethics and the moral 
questions confronting ethicists and laypeople alike in Africa. Like Africa, ethics brewed in an African pot deals with the often puzzling extremes of life and death, humanity and depravity, civilization and stagnation.

Talking about ethics in Africa as a brew offers us a fitting figure of speech. The imagery of a brew evokes the processes of concocting local beer in several parts of Africa. Any kind of brew is never made of one ingredient only; it is a mixture of many elements. Whether it is chibuku in Zimbabwe, burukutu in Nigeria, or changa' $a$ in Kenya, the process always involves a variety of ingredients. This variety notwithstanding, there remains a basic element that forms the core of the brew-sometimes it is banana, or millet, or maize, or honey. In this sense the imagery of a brew typifies how ethics works in Africa.

What is the core of ethics brewed in an African pot? What principle underpins ethical and moral constructs in Africa? In the ethics of this vintage, two themes seem prominent as the principal focus of ethical inquiry in Africa. The first relates to the notion of life, the second to community.

Amid a diversity of opinions, a consensus exists among theologians and ethicists that "the foundations and purpose" of ethics is summed up under the rubric "Life." Central to the systems of ethical reasoning in Africa is the insight that "the strengthening and the growth of life are the fundamental criteria . .. in the realm of ethics." 1 As a general principle, in Africa, ethics turns on the notion of life. Speaking about the tropical core of ethics in Africa, the Tanzanian moral theologian Laurenti Magesa, whose authority is considerable in African theology, has argued that

everything is perceived with reference to this [life]. It is no wonder, then, [that] Africans quickly draw ethical conclusions about thoughts, words, and actions of human beings, or even of "natural" cosmological events, by asking questions such as: Does the particular happening promote life? If so, it is good, just, ethical, desirable, divine. Or, does it diminish life in any way? Then it is wrong, bad, unethical, unjust, detestable. . . This most basic understanding of morality in African Religion is incorporated systematically in the people's way of life... . It constitutes what Africans perceive as the mystique of life. ${ }^{2}$

In sum, across the variegated landscape of ethical analyses and debates in Africa, "all principles of morality and ethics are to be sought within the context of preserving human life and its 'power' or 'force."'3

To grasp the full meaning of this principle of life, we would need to think of it as more than just the biological perpetuation of the human species or the fact of human existence. For those African ethicists who have written about this central principle, Life represents the ultimate common good, the shared patrimony of the group, and the burden of care incumbent on each member. ${ }^{4}$ Life is the guarantee of wholeness and universal harmony within and between the 
material and the spiritual realms. Furthermore, Life creates an unconditional duty or responsibility toward action. Thus, to be morally upright is to act deliberately in favor of human life. Alternately, the witch or the sorcerer is the person who undermines the collective life force of the group.

It is important to situate the principle of life or life force as the norm of behavior and as a fundamental criterion for moral judgment in a larger, spatial context. The understanding of life as the "foundation and purpose" of ethics extends to the universe of plants, animals, and nature. Within this ethical framework, Life represents an expansive and inclusive experience.

The notion of expansiveness of life relates to the fact that life is not construed only as a reality constituted by the living; it also includes the ancestors and the yet-unborn. Furthermore, the category of life extends to and includes the natural universe. In this sense, therefore, from an African religio-cultural perspective, the moral imperative to protect human life also warrants the protection of sacred forests, trees, rivers, mountains, streams, and animals. This moral imperative or duty to protect the physical environment is founded on the vital link between the survival of human life and the environment. To protect the environment is to protect human life, since the survival of the latter ultimately depends on the survival of the former. ${ }^{5}$

In connection with the principle of life as the core of ethical discourse in Africa, there are two somewhat surprising facts worth mentioning as paradoxically at odds with this principle. First, for all the emphasis on the holistic claims and inclusiveness of an ethical tradition based on the concept of life, critical studies in ethics and the integrity of creation remain strikingly scant. Concern for the integrity of creation is mentioned as a passing comment in the preparatory documents of the 2009 African Synod, although the final synodal propositions attempt to cover this lacuna. ${ }^{6}$ Second, the emphasis on life as the core of ethics in Africa appears contradicted by human-instigated, large-scale destruction of life in various contexts. These two observations underscore the necessity of rethinking and of challenging the traditional idea of life as "foundation and purpose" of ethics in Africa.

Life as the foundation and purpose of ethics in Africa forms part of a wider claim concerning another moral category, namely, community. Community and relatedness are central to the way in which most Africans understand, interpret, and judge their action in society. ${ }^{7}$ In African ethics, community defines the space where the moral agent is located, and his or her actions are assessed for their moral rectitude vis-à-vis other members of the community. Because life is construed as a shared value or the ultimate common good, ethics founded on the notion of life as an "all-encompassing moral category" allows for a wide participation by all members of a particular community in setting the criteria for acting morally and making ethical judgments on what is right. ${ }^{8}$ 
In connection with the fundamental value of community and relatedness in assessing behavior and action, the literature on ethics in Africa speaks of "palaver," a term that roughly translates as "dialogue," "participatory discourse," or "consensus building." As Congolese ethicist Bénézet Bujo has phrased it, palaver is a means of establishing "an ethical authority." Palaver allows every member of the community to exercise an active voice in examining the viability of particular traditions "so that all the ethical norms can be either confirmed or changed. The ethical norms confirmed or newly established and justified in the palaver obligate everyone, and this means that every individual member and the whole family ... [or community] are responsible for keeping these norms." 9 Ordinarily, in the context of palaver, norms and values would not be the object of categorical decisions and impositions foisted on the community by the leader. Accordingly, some African ethicists, such as Bujo, have argued that the dictatorships and authoritarianism that have become widespread in African political life since independence in the 1960s represent a relatively recent development. ${ }^{10}$ Essentially, African palaver ethics claims to be inclusive since it gives everyone, including "the invisible community of the ancestors," a voice in the formulation of norms and judgments. 11

I argue that Bujo's claim to a democratic and inclusive process of conducting ethical discourse in Africa should be questioned for several reasons. I believe there are assumptions here that are in need of more critical examination than those who argue the inclusiveness of palaver ethics in Africa have seemed willing to do. Let me give one example, obvious to me and others, that explains my reservation.

\section{Actors and Voices-"Not Counting the Women and Children"}

For all the variations that a survey of the landscape of ethics and moral questions in Africa reveals, there is a methodological limitation common to the various approaches. This limitation concerns the gender composition of the continent's cast of ethicists and moral theologians. On this issue I see no risk of generalization. Speaking from the perspective of Roman Catholic ethics, the definition, study, and debate of moral issues in Africa continue to be determined by a patriarchal hierarchy, dominated by the ordained clergy, and confined almost exclusively to the setting of seminary training. This state of affairs is also true for other Christian denominations and their schools of theology in Africa. Women's voices remain exceptionally rare in a domain where "men possess the tools of power as the main dispensing agents of God."12 Like formal theology in Africa, the boundary, questions, and nature of ethics are delineated by a powerful cast of religious and clerical elites. ${ }^{13}$ The rarity of literature on ethics authored by African women is so patent and definitive that it needs no justifica- 
tion. However, supposing that my observation is correct, the question arises: what happened and continues to happen to women's voices in the domain of African ethics? I offer here some beginnings of a response from my perspective as an official member of the clerical cast.

The nature and structure of moral theology as taught in many seminary contexts with which I am familiar is largely scholastic and heavily overlaid with traditions steeped in medieval metaphysics and philosophical discourse. This penchant for a purely academic understanding of ethics and moral theology explains in part the absence of women's voices. Sadly, it ignores the vast materials for ethical discourse contained in the untapped narratives of African women. These are women who are not professional theologians but who confront on a daily basis many pressing moral issues in the contexts of diseases, human trafficking, human rights violations, ecological degradation, armed conflict, and climate change. ${ }^{14}$ In church as well as in society, African women live at the frontier of a variety of moral issues and questions affecting the quality of human life in Africa. Ghanaian Methodist woman theologian Mercy Amba Oduyoye has argued the uniqueness of theology or ethics understood from the particular perspective of African women. For Oduyoye, this theological ethics is "dynamic and vigorous, not easily trapped between the covers of a book." 15 Women's approaches to moral questions exist in the narratives of life experienced and expressed in multiple contexts. A broader methodology is required to turn these narratives into coherent ethical syntheses. Oduyoye summarizes the formidable challenges African women face in elaborating a theological and ethical discourse that honors and includes their voices: "By the time a woman has spent her energy struggling to be heard, she has barely the energy left to say what she wanted to say."16 I perceive a significant ethical issue in Oduyoye's remarks that confirms my reservations on the inclusive nature of palaver ethics in Africa. The absence of contributions from women ethicists and moral theologians in Africa implies that a balanced, holistic, and just ethical debate will remain an elusive proposition in a cultural and religious setting that enshrines the dominance of male authorities while it restricts the education of its women.

In regard to women and ethics in Africa, I draw attention to a ray of hope in the domain of ethics in Africa. In 2009 Catholic Theological Ethics in the World Church pioneered an unprecedented Scholarship Program for the Advanced Training of African Women in Theological Ethics. ${ }^{17}$ Thanks to this program, seven African women are in various stages of graduate and doctoral studies in Kenya, Uganda, Cameroon, and D.R. Congo-all of them in the field of theological and applied ethics. This unprecedented initiative is led by James Keenan, SJ, chair of Catholic Theological Ethics in the World Church.

I describe this initiative as unprecedented because I believe that the most promising impulse for renewing ethics in Africa will come from the hitherto missing but now emerging repository of narratives and voices that have largely 
escaped the cooptation by dominant hierarchical and political forces while remaining faithful to the practical issues that shape everyday life on the continent. These narratives and voices belong in large measure to African women.

A further consequence to the patriarchal and hierarchical dominance of ethical discourse in Africa is due to the rather heavy bias toward the preservation of venerable moral traditions, assumptions, and presuppositions. As a result, responses to moral questions tend to follow a familiar trajectory. First, these responses appear reactionary, with the emphasis on preserving traditions and safeguarding ecclesiastical authority. Second, they make categorical claims and deontological statements rather than a critical reexamination of the bases and foundations of moral theology. Third, they appear to be obsessed with sexual morality. Given the urgency of moral issues confronting the continent, it is both morally irresponsible and reprehensible to continue brewing ethics in Africa using only a limited set of fossilized principles, yielding thereby only a bitterly spoiled brew.

\section{A Roman Catholic Affair}

Contentious as the claim may sound, in several parts of Africa, ethics as a systematic elaboration of moral principles that shape human action in social, economic, political, cultural, or religious milieus seems a largely Roman Catholic affair. Obviously, Catholicism enjoys a long tradition of ethical reflection and the benefit of a generalized codification of its traditions in a long documentary history, a catechism, and, more recently, in its Compendium of the Social Doctrine of the Church. ${ }^{18}$ The approaches to moral questions in Africa reveal a pattern in which most mainline Protestant churches focus primarily on social issues while the burgeoning Pentecostal churches and African Independent Churches carefully circumvent these issues. ${ }^{19}$ Characteristically, this latter group of churches continues to promote the gospel of economic prosperity and the strict incompatibility of religion and politics. ${ }^{20}$

Concerning ethics in Africa, Protestant contributions of outstanding importance exist as periodic joint statements suffused with biblical references used often, unfortunately, as a substitute for critical analysis. In this regard, institutions such as All Africa Conference of Churches hold the pride of place in Protestant ethics. Their preferred means of pronouncing on moral questions are ecumenical covenants, charters, and declarations, which focus on a wide but disparate spectrum of issues, encompassing globalization, human rights, governance, gender justice, environmental conservation, the death penalty, forced displacement, disability rights, and others. ${ }^{21}$ Despite these contributions, the consistency and scope of Roman Catholic literature outstrips the collective output of Protestant and other churches' attempts at doing ethics in Africa. 
In a related context, as mentioned earlier regarding the centrality of the principle of life, although there is much interaction between the traditions of African religion and Christianity on elaborating ethical discourses, the same cannot be said about the second-most dominant religion in Africa, Islam. It is a daunting task to find systematically articulated ethics from the perspective of Islam in Africa. Without indulging a lengthy parenthesis on Islamic ethics in Africa, the concert between African religion and Christianity on a variety of moral issues reveals another interesting aspect of ethics in Africa: both the African religion and Christianity adopt elements of taboo and denial as a means of controlling ethical discourse.

\section{Taboos and Denial}

There are some issues in ethics that frequently have been distorted when viewed through the twin lenses of African culture and Christian ethics. I use the notion of taboo within the cultural reality of Africa to illustrate the fact that in surveying the ethical landscape in Africa, whether in church or in society, the space for a credible, critical, and public moral discourse appears severely constricted. This situation stems from the tendency to impose prohibitions on the debate of some moral issues erroneously considered as "Western" and, therefore, "un-African." 22 Culture colludes with dominant orthodoxies in Christian ethics to create a formidable alliance that denies the existence of a set of moral issues even in the face of multiple manifestations. The danger here is for African ethicists to consider Christian ethics as simply an extension of culture modified perhaps only by its biblical input. Furthermore, the denial of certain moral issues is rarely substantiated by force of critical ethical analysis. On the contrary, the norm is to stifle debate. In this context, the moral theologian is rarely free to conduct an open debate on issues that carry the pejorative label "Western." My point is not to suggest that the controversies surrounding these moral issues are peculiar to Africa, but in many parts of Africa the approaches to these issues are largely constrained by a culture of taboo and denial.

Interestingly, on some of these ethical taboos, church and state in Africa find common ground in their attempt to preserve what is considered pristine African religious values and cultural heritage while prohibiting open debate on contentious moral issues. Given the evangelical fervor with which taboos and denials are promulgated, doing ethics in certain contexts of Africa exposes professional ethicists to multiple dangers and the perils of sanction, silencing, or worse.

To take but one example, the denial, demonization, and criminalization of same-sex relationship enjoys the blessing of ecclesiastical authorities and carries the sanction of several African governments but not the benefit of an open, 
credible, and honest ethical debate. Those who argue the nonexistence of samesex relationship as a matter for ethical discourse in Africa promote a pervasive and authoritative denial of same-sex relationships with a "culture of silence," unsupportable by evidence, reinforced and "imposed by force of ecclesiastical anathemas" and draconian legislation by the state. ${ }^{23} \mathrm{My}$ intention is not to pronounce on the morality or immorality of questions regarding the morality of same-sex relationships. Rather, the salient point is the absence or the suppression of evidentiary investigations and a healthy ethical discourse and debate in the name of African religion, culture, and Christianity. Again, this situation reveals another consequence of an ethical discourse dominated and regulated by the hierarchy and clergy-ethicists-while the former sets the agenda, the latter lose their integrity and freedom to conduct a credible moral discourse. The fine old English saying, "He who pays the piper dictates the tune," is applicable here.

\section{A League of Moral Issues: The "Big Five"}

The suppression of debate notwithstanding, numerous issues are in need of sustained ethical analyses and debates across Africa. In Kenya, where I live, a country that thrives on tourism, we speak of the "Big Five"-a list of must-see big game: lion, elephant, rhino, buffalo, and leopard. I refer here to what I consider as the top five pressing moral issues brewing in Africa today, using this list as metaphor.

1. The Lion, governance. The lion of governance is the root of all evil. Since their independence, most African countries have struggled with the challenge of establishing stable and functional systems of governance. The rate of success remains generally unimpressive. A long list of ethical issues can be linked directly to the failure of governance and leadership endemic to most African nations-poverty, human rights violations, social inequities, corruption, impunity, wars, displacement of peoples, and so on.

2. The Elephant, integrity of creation. This elephant (in the living room) is not a new problem. As mentioned earlier, the moral imperative to honor and preserve the environment appears innate to ethics and religion in Africa. The continent enjoys the unprecedented reputation of producing the first Nobel Peace laureate in the area of integrity of creationWangari Maathai. ${ }^{24}$ However, the present debate on the integrity of creation lacks urgency and a critical edge on a continent already reeling from the environmental hazards that are directly or indirectly tied to the economic growth, abundance, and consumption of Western as well as emerg- 
ing Eastern economies. To date and in spite of the moral imperative regarding the environment, climate change has attracted remarkably scant scholarly attention in African ethics. Fortunately, the 2009 African Synod has corrected the glaring omission of this issue in its original agenda by acknowledging the "deleterious effects of climate change, global warming, natural calamities" and the responsibility of Christian communities to "make the earth habitable beyond the present generation and to guarantee sustainable and responsible care of the earth ... [ [by promoting] environmental education and awareness." 25 Integrity of creation defines an agenda for ethics in Africa alternative to the established tradition of moral discourse.

3. The Rhinoceros, genetically modified organisms. An herbivore, the rhino is particularly vulnerable to the unintended (or undisclosed) consequences resulting from widespread use of genetically modified food. As one of the places on Earth where hunger remains endemic, the entire African continent now has to contend with the challenges of genetically modified organisms, GMOs. With Africa's weak systems of governance, multilateral companies seem poised to hold the continent's masses of poor and hungry ransom to profit-driven biotechnological experimentations. The ethical implications of this technology seem largely underresearched in African ethics. The challenge is to devise an appropriate framework for addressing the ethical challenges of GMOs from an African perspective and in African contexts.

4. The Buffalo, resource extraction. Another herbivore that is widespread over diverse terrain, the buffalo depend on a ready supply of water, one of the planet's most valuable resources. The twenty-first century is witnessing a renewed focus on Africa as the source of raw materials to propel economic growth in both the West and the East. This contemporary scramble for Africa's natural and mineral resources marks another phase of economic exploitation. From the scramble for coltan in Eastern D.R. Congo to the illegal mining of "blood diamonds" in Sierra Leone and the exploitative drilling of "black gold" in Nigeria, the continent is littered with the toxic repercussions, particularly to scarce water supplies, of unethical quests for its natural resources. The data paints a picture of exploitation, violence, conflict, and political instability. This state of affairs, closely linked to the integrity of creation, is in urgent need of a critical ethical analysis.

5. The Leopard, domestic justice. A popular mantra among ecclesiastics and moral theologians in Africa, particularly in the area of social ethics, is the claim that the Roman Catholic Church is the nonpartisan "conscience of society" and "voice of the voiceless." Perhaps like the leopard-strong, 
swift, and steady-the Church is the official overseer of public morality. The Church has played and continues to play this role faithfully, using its preferred means of pastoral letters, communiqués, and public declarations. One consequence of this externalization of the ethical focus of ecclesia in Africa is the inability to deal comfortably with internal or domestic ethical issues, such as inequality in ministry, just wages for pastoral workers, and various forms of abuse of ecclesiastical and clerical power and authority. The Church in Africa would benefit immensely from an ethics that focuses on its domestic moral challenges.

Let me make two observations regarding these "Big Five." First, none of them is unique to Africa, nor do they exhaust the list of questions, problems, and issues in African ethics. However, given the present predicament of the continent, taken as a whole and considered in their diverse aspects, these five issues constitute a matter of importance and debate, and pose significant challenges to social ethics in Africa and Christian ethics in general. Second, these urgent moral issues generate questions that strain traditional ethical categories from seminary training and education and from the principle of life and palaver. Third, they go a long way in explaining the preference for social ethics in Africa compared to fundamental moral theology. To give but one example, from both personal knowledge and anecdotal evidence, most African Jesuit students who come to study theology in North America gravitate toward social ethics-and the moral issues in African politics, public policy, development, human rights, refugees, HIV and AIDS, and so on. I believe that Africa's most pressing challenges are political, economic, and religious. Understandably, then, there is an abundance of publications by African Jesuit students and other students in social ethics. These publications outweigh studies in the equally pressing need for foundational ethics or fundamental moral theology in Africa, for Africa.

One conclusion suggests itself from a careful consideration of the league of moral issues. Across Africa, ethics will almost always be applied ethics. Popular titles would conceivably include "Ethics \& AIDS in Africa," "Applied Ethics and Africa's Social Reconstruction," "Ethics and Public Policy in Africa," and so on. As argued earlier, foundations are as important as applied (social) ethics, and so are schools of ethical syntheses. But on a continent where the majority is caught in what Jeffrey Sachs has described as the "poverty trap," too many people are "too ill, hungry, or destitute even to get a foot on the first rung of the development ladder." 26 The validity and coherence of any ethical construct will be tested and judged severely in the crucible of burning issues and questions that shape the systems of ethics in Africa.

Consider one illustration of this predominance of applied ethics in Africa, the proliferation of Justice, Development, and Peace Commissions (JDPCs) on 
the continent. Different permutations of the constituent elements of JDPCs are variously known as Justice and Peace Commissions, Faith and Justice Commissions, and Justice, Peace, and Integrity of Creation. ${ }^{27}$ The common thread among these commissions is the concern for socioeconomic and political issues from a faith-based perspective. Generally, JDPCs and their variants are ecclesial-based institutions that seek to address a wide spectrum of social, economic, political, and development issues. Typically, the guiding principles and criteria for action are drawn from scripture and, when Catholic, traditions of the Church's social teaching. While leaders of JDPCs may not be trained ethicists, increasingly they rely on the input of moral theologians and ethicists to clarify and understand the theoretical foundations of their direct involvement in issues of social concern. Although JDPCs also struggle with prevailing ecclesiastical and clerical control, the situation appears to be changing as many JDPCs and similar institutions increasingly open up to the participation of lay faithful.

\section{Suggestions for a Global Ethical Partnership}

According to an African proverb, a chicken develops a headache when it sees another chicken on the dinner table. The moral questions and ethical issues that brew in Africa are global in scope; they should also provoke some headache among ethicists in other parts of the globe.

I conclude by stressing the moral imperative to develop a global solidarity for a comprehensive ethical partnership as one remedy for the headache that accompanies a bitterly spoiled brew. Let me suggest three priorities for action in addition to the example of the sponsorship of African women to advanced theological studies by the initiatives arising from Catholic Theological Ethics in the World Church:

- A long-term commitment to gender-sensitive collaboration in the training of African ethicists to acquire specific, professional competence in diverse fields of fundamental and applied ethics appropriate to the needs of the continent, a collaboration that is beyond the traditional program of seminary-based moral theology.

- Carefully planned exchange of personnel across various fields of ethics to enable African ethicists to gain particular skills, broaden their experience, and enhance their confidence through international exposure.

- Functional networks of interdisciplinary and cross-cultural scholarship, research, and publication in dealing with moral questions that are global in scope, albeit affecting Africa in a particular or unique way. 
The goal of ethics brewed in an African pot is to reinforce and enhance the moral traditions of abundant life for humanity. This African brew is rooted in a spirituality of the fullness of life and promotes a celebration of life, even in the midst of misery. In Africa, a brew is never meant for mere inebriation; it is a catalyst for celebration. That celebration, in turn, promotes palaver and the coexistence of divergent or opposing views and personalities working together and in solidarity for an African common good. My wish is that this celebration of life, tolerance of divergent opinions, and commonality of purposes becomes constitutive of ethics brewed in an African pot.

\section{Notes}

1. Bénézet Bujo, The Ethical Dimension of Community: The African Model and the Dialogue between North and South (Nairobi, Kenya: Paulines Publications Africa, 1997), 27.

2. Laurenti Magesa, Anatomy of Inculturation: Transforming the Church in Africa (Nairobi, Kenya: Paulines Publications Africa, 2005), 77.

3. Ibid.

4. See Bujo, Ethical Dimension of Community; Robert Schreiter, ed., Faces of Zesus in Africa (Maryknoll, NY: Orbis, 1991); Charles Nyamiti, Christ Our Ancestor: Christology from an African Perspective (Gweru, Zimbabwe: Mambo Press, 1984); and Laurenti Magesa, African Religion: The Moral Traditions of Abundant Life (Maryknoll, NY: Orbis Books, 1997).

5. Agbonkhianmeghe E. Orobator, "Ethics of HIV/AIDS Prevention: Paradigms of a New Discourse from an African Perspective," in Applied Ethics in the World Church: The Padua Conference, ed. Linda Hogan (Maryknoll, NY: Orbis Books, 2008), 149.

6. The second African Synod took place in October 2009 in Rome. During the Synod, ecclesiastical, religious, and lay representatives of the church in Africa addressed pertinent issues related to justice, reconciliation, and peace in church and in society in Africa. For propositions of the Synod, see "II Coetus specialis pro Africa" ("Propositions of the 2nd African Synod"), "Elenchus finalis propositionum," Resources for the 2009 Second African Synod (November 2009, http://maryknollafrica.org/Documents/Resources\%20for\%20 the $\% 202009 \% 20$ Second\%20African\%20Synod.htm. Also available on the Vatican website, www.vatican.va/roman_curia/synod/documents/rc_synod_doc_20091023_elencoprop-finali_en.html.

7. Okechukwu Ogbonnaya, On Communitarian Divinity: An African Interpretation of the Trinity (New York: Paragon House, 1998), 14.

8. Ibid.

9. Bénézet Bujo, Foundations of an African Ethic: Beyond the Universal Claims of Western Morality (Nairobi, Kenya: Paulines Publications Africa, 2003), 73-74.

10. Ibid, 77.

11. Ibid, 79.

12. Nicholas Otieno, Human Rights and Social fustice: Cultural, Ethical and Spiritual Imperatives (Nairobi, Kenya: All Africa Conference of Churches, 2008), 13.

13. Paul Gifford, Cbristianity, Politics and Public Life in Kenya (London: Hurst \& Company, 2009), 82. 
14. See Edna Maluma, "Abundant Life for Women and Children?" in Claiming the Promise: African Churches Speak, ed. Margaret S. Larom (New York: Friendship Press, 1994), 59-61; and Musimbi Kanyoro, "When Women Rise the Earth Trembles," in Claiming the Promise, 63-67.

15. Mercy Amba Oduyoye, Introducing African Women's Theology (Cleveland, OH: Pilgrim Press, 2001), 22.

16. Mercy Amba Oduyoye, Beads and Strands: Reflections of an African Woman on Christianity in Africa (Maryknoll, NY: Orbis Books, 2004), 75.

17. Catholic Theological Ethicists in the World Church is a global network of theological ethicists engaged in dialog on a variety of ethical issues across a wide spectrum of theological perspectives, schools of thought, and opinions. See www.catholicethics.com.

18. Compendium of the Social Doctrine of the Church (Nairobi, Kenya: Paulines Publications Africa, 2005).

19. See Paul Gifford, African Christianity: Its Public Role (Bloomington: Indiana University Press, 1998).

20. See Paul Gifford, "Prosperity: A New Foreign Element in African Christianity," Religion 20 (1990): 373-88; Gifford, African Christianity; Rosalind I. J. Hackett, "The Gospel of Prosperity in West Africa," in Religion and the Transformations of Capitalism, ed. Richard H. Roberts, 199-214 (London: Routledge, 1995); James F. Ndyabahika, "The Attitude of the Historical Churches to Poverty and Wealth: A Challenge for African Christianity," Africa Journal of Evangelical Theology 23, no. 2 (2004): 199-214; and David T. Williams, "The Heresy of Prosperity Teaching: A Message for the Church in Its Approach to Need," Journal of Theology for Southern Africa 61 (December 1987): 33-44.

21. See Otieno, Human Rights and Social fustice, 159-85.

22. Okiya Omtatah Okoiti, "Unlike Christianity and Islam, Homosexuality Is Un-African," Daily Nation, November 2, 2009.

23. Shokoloko Bangoshe, "Homosexuality and Africa: Strange Bedfellows?" Human Development 29, no. 4 (Winter 2008): 15.

24. A Kenyan environmental activist, Dr. Wangari Maathai founded the Green Belt Movement in the 1970s to regenerate the environment by planting trees. The recognition of her work by the Nobel Committee in 2004 confirmed the critical importance of the integrity of environment as a factor of peace building, development, and democracy. See her memoir, Wangari Maathai, Unbowed: One Woman's Story (London: Heinemann, 2006).

25. II Coetus specialis pro Africa, "Elenchus finalis propositionum," Proposition, 22.

26. Jeffrey Sachs, The End of Poverty: Economic Possibilities for Our Time (New York: Penguin, 2005), 18.

27. Consider, for example, the Justice and Peace Commission of the Archdiocese of Cape Town, South Africa, whose "vision is a transformed society in which there will be human dignity, freedom, equality and peace. Our mission is to confront social and political injustice and build a culture of respect for human rights in South Africa, so that all members of society may enjoy their basic constitutional rights." Justice and Peace Commission (2008), http://justiceandpeace.co.za/; the Justice, Development and Peace Commission, Catholic Diocese of Ijebu-Ode, Ogun State, Nigeria, whose "mission is to promote sustainable and integral human development through holistic empowerment approach, enhancing effective structural transformation of the society without any form of discrimination. To accomplish this mission, JDPC works in the areas of human rights, election monitoring, promotion of democracy, gender, women promotion, agricultural development and extension, microfinance, prison reform and welfare, rehabilitation of refugees, 
emergency relief, budget advocacy and Resource Centre." Wiser Earth (2005), www .wiserearth.org/organization/view/50c7c55a0d55caf60eea19449689be4e; and The Catholic Centre for Justice, Development and Peace, whose "Vision [is] a Zambian society where every person is free to fully attain integral human development and live in harmony. [And] Mission [as] the Catholic Centre for Justice, Development and Peace (CCJDP), a Faith Based Organisation, inspired by gospel values and the Social Teaching of the Church, will promote integral human development, economic justice, social justice, human dignity and empowerment of the less privileged in society through conscientization, advocacy, research and training, and institutional strengthening." Caritas Zambia (2008), www.ccjdp .org.zm/. 